\title{
HUBUNGAN PERILAKU IBU DALAM PEMENUHAN GIZI PADA ANAK 1000 HARI PERTAMA KEHIDUPAN/ GOLDEN PERIOD DENGAN STATUS GIZI BALITA DI DESA SITANGGAL KECAMATAN LARANGAN KABUPATEN BREBES TAHUN 2018
}

\author{
Laelatul Mubasyiroh, Ziyadatul Chusna Aya
}

Akbid YPBHK Brebes

E-mail: ellaaxella@gmail.com

\begin{abstract}
Abstrak
Salah satu perhatian SDGs pada sektor kesehatan terdapat pada tujuan. meningkatkan gizi. Berdasarkan data riset kesehatan dasar (Riskesdas) 2013 prevalensi balita gizi buruk sebesar 5,7 persen dan kekurangan gizi 13,9 persen. Langkah awal yang paling penting untuk dilakukan adalah pemenuhan gizi pada anak sejak dini, bahkan saat masih di dalam kandungan atau yang dikenal dengan 1000 Hari Pertama Kehidupan. Ibu memegang peranan yang sangat penting dimana perilaku pemenuhan gizi yang baik dapat meningkatkan status gizi anak. Penelitian ini bertujuan untuk mengetahui hubungan perilaku ibu dalam pemenuhan gizi pada anak 1000 hari pertama kehidupan dengan status gizi Balita di Desa Sitanggal Kabupaten Brebes.Penelitian ini dilakukan menggunakan deskriptif korelasi kepada 51 responden Ibu balita 0-3 tahun dengan membagikan kuesioner dan status gizi diukur dengan menimbang dan melihat dengan KMS. Hasil penelitian menunjukkan ibu sebagian besar mempunyai perilaku yang kurang yaitu $51,0 \%$, sedangkan status gizi anak sebagian besar anak memiliki status gizi kurang yaitu 49,0\%. Berdasarkan hasil Uji statistik dengan chi square diperoleh $\mathrm{p}=0,003<\alpha$ $(0,05)$ dapat disimpulkan bahwa ada hubungan perilaku ibu dalam pemenuhan gizi pada anak 1000 hari kehidupan dengan status gizi balita. Perlunya meningkatkan pemberian gizi, dan pemantauan status gizi balita di setiap posyandu untuk memantau tumbang anak balita.
\end{abstract}

Kata kunci:Balita, Ibu Balita, Perilaku, Pemenuhan Gizi 1000 Hari Pertama Kehidupan, Status Gizi,

\section{Pendahuluan}

Salah satu perhatian SDGs pada sektor kesehatan terdapat pada tujuan menanggulangi kelaparan dan kemiskinan, mencapai ketahanan pangan, meningkatkan gizi, serta mendorong pertanian yang berkelanjutan. Selain itu, terdapat dua target yang diharapkan dapat terwujud pada tujuan SDGs ini. Target pertama yaitu, pada tahun 2030, mengakhiri kelaparan dan menjamin akses pangan yang aman, bergizi, dan mencukupi bagi semua orang, khususnya masyarakat miskin dan usia rentan seperti bayi. Sedangkan target kedua yaitu, pada tahun 2030, mengakhiri segala bentuk malnutrisi, termasuk mencapai target internasional 2025 untuk penurunan stunting dan wasting pada balita dan mengatasi kebutuhan gizi remaja perempuan, wanita hamil dan menyusui, serta lansia (Depkes $\mathrm{RI})$.

Berdasarkan data riset kesehatan dasar (Riskesdas) 2013, secara nasional 
prevalensi balita gizi buruk sebesar 5,7 persen dan kekurangan gizi 13,9 persen. Prevalensi balita stunting di Indonesia Prevalensi di Indonesia sebanyak 37,2\%, Wasting $12,1 \%$, dan 19,6\% overweight per 1.000 kelahiran hidup (UNICEF, WHO, and World Bank, 2014 dalam Achadi, 2015). Sedangkan Pemantauan Status Gizi (PSG) di Kabupaten Brebes jumlah balita dengan gangguan gizi (Stunting) di tahun 2010 yaitu sebesar 22,10\%, pada tahun 2011 sebesar 22,54\%, tahun 2012 sebesar 19,57\% dan ditahun 2013 adalah 17,14\%. (Profil Dinkes Brebes, 2014). Sedangkan jumlah bayi baru lahir yang ditimbang sebanyak 33.312 balita, sebanyak 1.572 balita $(4,72 \%)$ dikategorikan BBLR yaitu Berat Bayi Lahir Rendah. Kondisi ini dapat terjadi karena diantaranya dipengaruhi oleh faktor gizi ibu hamil yang kurang baik (Profil Dinkes Brebes, 2015).

Untuk mencetak anak Indonesia yang sehat dan cerdas, langkah awal yang paling penting untuk dilakukan adalah pemenuhan gizi pada anak sejak dini, bahkan saat masih di dalam kandungan atau yang dikenal dengan 1000 Hari Pertama Kehidupan (1000 HPK). 1000 HPK dimulai sejak dari fase kehamilan (270 hari) hingga anak berusia 2 tahun /730 hari (Achadi EL, 2014).

Gerakan 1000 hari pertama kehidupan merupakan suatu gerakan percepatan perbaikan gizi yang diadopsi dari gerakan Scaling up Nutrition(SUN) Movement yang merupakan suatu gerakan global dibawah koordinasi sekertaris jendral PBB. Tujuan global dari Scaling up Nutrition (SUN) adalah untuk menurunkan gizi yang dibuktikan secara ilmiah merupakan metode untuk menentukan kualitas kehidupan seseorang (Erna, 2017)

Untuk pemenuhan gizi pada anak diantaranya adalah dengan menggunakan pendekatan aksi nutrisi essensial (The Essential Nutrition Actions/ENAs) yang dicanangkan WHO yaitu pemberian zat besi dalam jumlah tertentu selama kehamilan, persiapan menyusui, nutrisi selama menyusui, pemberian Asi ekslusif, pemberian multivitamin dan asupan gizi seimbang (BAPENNAS, 2011).

Dengan meningkatkan kuliats kesehatan ibu hamil dan anak sejak dalam kandungan akan didapatkan generasi penerus yang lebih produktif sehingga dapat memajukan kualitas generasi muda. Sembilan pesan inti 1000 hari pertama kehidupan yaitu, Selama hamil, makan makanan beraneka raga, memeriksa kehamilan $4 \mathrm{x}$ selama kehamilan, minum tablet tambah darah, bayi yang baru lahir Inisiasi Menyusui Dini (IMD), memberikan ASI eksklusif selama 6 bulan, menimbang BB bayi secara rutin setiap bulan, memberikan imunisasi dasar wajib bagi bayi, melanjutkan pemberian ASI hingga berusia 2 tahun, memberikan MP ASI secara bertahap pada usia 6 bulan dan tetap memberikan ASI (Irawati, 2018).

Seribu hari pertama kehidupan telah disepakati oleh para ahli di seluruh dunia sebagai saat yang terpenting dalam hidup seseorang. Sejak saat perkembangan janin di dalam kandungan, hingga ulang tahun yang kedua menentukan kesehatan dan kecerdasan seseorang. Makanan selama kehamilan dapat mempengaruhi fungsi memori, konsentrasi, pengambilan keputusan, intelektual, mood, dan emosi seorang anak di kemudian hari (Irawati, 2018).

Anak-anak yang mengalami hambatan dalam pertumbuhan disebabkan kurangnya asupan makanan yang memadai dan penyakit infeksi yang berulang, dan meningkatnya kebutuhan metabolik serta mengurangi nafsu makan, sehingga meningkatnya kekurangan gizi pada anak. Keadaan ini semakin mempersulit untuk mengatasi gangguan pertumbuhan yang akhirnya berpeluang terjadinya stunted.

Pada pemenuhan gizi seorang balita, ibu meme-gang peranan yang sangat penting. Ibu merupakan orang yang paling dekat dengan anak, orang pertama yang berhubungan dengan anak, dan yang memberikan alokasi waktu lebih banyak dalam pengasuhan anak. Sikap merupakan faktor yang memengaruhi perilaku 
kesehatan seseorang. Perubahan sikap secara berkelanjutan dapat memengaruhi perilaku seseorang, dimana perilaku pemenuhan gizi yang baik dapat meningkatkan status gizi anak (Apooh, Yaa, \& Krekling, 2005). Status gizi adalah keadaan tubuh sebagai akibat konsumsi makanan dan penggunaan zat-zat gizi. Keadaan tersebut dapat dibedakan dengan status gizi kurang, baik, dan lebih (Almatsier, 2001).

Penelitian ini bertujuan untuk mengetahui hubungan perilaku ibu dalam pemenuhan gizi pada anak 1000 hari pertama kehidupan/ Golden Perioed dengan status gizi Balita.

\section{Metode Penelitian}

Jenis penelitian yang dilakukan berdasarkan jenis data adalah adalah penelitian kuantitatif dan berdasarkan cara pengumpulan data adalah survey yang non eksperimen dengan desain penelitian deskriptif korelasi yang bertujuan mengungkap hubungan korelasi survei deskriptif perilaku ibu dalam pemenuhan gizi pada anak 1000 hari pertama kehidupan/ Golden Perioed dengan status gizi.

Pendekatan yang digunakan adalah menggunakan studi cross sectional ialah suatu penelitian untuk mempelajari dinamika korelasi antara faktor-faktor risiko dengan efek, dengan cara pendekatan, observasi atau pengumpulan data sekaligus pada suatu saat (point time approach). Artinya, tiap subjek penelitian hanya diobservasi sekali saja dan pengukuran dilakukan terhadap status karakter atau variabel subjek pada saat pemeriksaan. Populasi penelitian ini adalah semua ibu yang mempunyai balita di posyandu wilayah sitanggal,kriteria inklusi sampel adalah ibu yang mempunyai balita 0-3 tahun berjumlah
98. Sedangkan kriteria eksklusi sampel antara lain ibu yang mempunnyai anak cacat dan gizi buruk, sehingga didapatkan sampel sebanyak 51 responden. Adapun teknis pengambilan sampel menggunakan teknik simple random sampling yaitu pengambilan sampel dengan acak tanpa memperhatikan strata yang ada dalam anggota populasi.

Instrumen yang digunakan dalam penelitian ini berbentuk kuesioner terstruktur dengan item pertanyaan yang ditanyakan langsung kepada responden, dimana kuesioner tersebut dibuat sedemikian rupa sehingga responden hanya tinggal memilih atau menjawab jawaban yang sudah ada (hidayat, 2007). Dengan teknik wawancara dipergunakan untuk menilai perilaku ibu dalam pemenuhan gizi pada anak 1000 hari pertama kehidupan/ Golden Perioed sedangkan status gizi dapat dengan menimbang berat badan menggunakan timbangan dan dengan melihat pada lembar KMS. Variabel yang digunakan meliputi: perilaku ibu dalam pemenuhan gizi pada anak 1000 hari pertama kehidupan/ Golden Perioed dan status gizi.

Analisis univariat untuk mendiskripsikan karakteristik umur ibu, pendidikan ibu, pekerjaan ibu, perilaku ibu dalam pemenuhan gizi pada anak 1000 hari pertama kehidupan/ Golden Perioed dan status gizi kurang pada balita. Analisis bivariat menggunakan chi square, karena semua variabel penelitian dengan skala nominal untuk melihat perilaku ibu dalam pemenuhan gizi pada anak 1000 hari pertama kehidupan/ Golden Perioed dengan status gizi balita.

\section{Hasil dan Pembahasan}

Penelitian dilakukan pada 51 responden yang memiliki balita. 
Tabel 1. Karakteristik Responden

\begin{tabular}{ccc}
\hline KarakteristikResponden & jumlah & $\%$ \\
\hline Umur & & \\
$<20$ tahun & 0 & 0 \\
$20-30$ tahun & 10 & 19,6 \\
$>30$ tahun & 1 & 80,4 \\
Pendidikan & & \\
SD & 12 & 23,5 \\
SMP & 23 & 45,1 \\
SMA & 12 & 23,5 \\
PT & 4 & 7,8 \\
Pekerjaan & & \\
IRT & 30 & 58,8 \\
Petani & 3 & 59 \\
Swasta & 18 & 35,3 \\
PNS & 0 & 0 \\
Tidak pernah & & \\
pernah & 24 & 47,1 \\
Mengikuti Penyuluhan & 27 & 52,9 \\
\hline
\end{tabular}

Hasil survey menunjukkan ibu ratarata telah memiliki umur lebih dari 30 tahun (80,4\%). Menurut Huclock (1998), semakin cukup umur, tingkat kematangan dan kekuatan seseorang akan lebih matang dalam berfikir dan bekerja sehingga masih dapat menyerap informasi sebanyakbanyaknya. Umur berpengaruh dalam proses belajar menyesuaikan diri, seiring dengan bertambahnya umur seseorang maka semakin banyak pengalaman yang akan didapat dari lingkungan dalam membentuk perilakunya (Notoadmodjo, 2003).

Pendidikan ibu berdasarkan dengan hasil penelitian menunjukkan mayoritas subyek penelitian berpendidikan SMP yaitu sebanyak $23(45,1 \%)$. Semakin rendah tingkat pendidikan ibu, maka kemungkinan sulit bagi mereka untuk menangkap informasi maupun ide-ide termasuk tentang pengetahuan pemenuhan gizi pada anak 1000 hari pertama kehidupan/ Golden Perioed. Manusia membutuhkan pendidikan dalam kehidupannya. Tingkat pendidikan yang tinggi akan menambah pengetahuan yang dimiliki serta dapat membentuk suatu perilaku yang baik pula, termasuk di dalamnya berperilaku kesehatan (Aritama, 2000).

Pekerjaan ibu mayoritas mempunyai pekerjaan sebagai ibu rumah tangga yaitu sebanyak $30(58,8 \%)$. Hasil ini menunjukkan bahwa sebagian ibu memiliki waktu yang lebih banyak untuk mengasuh dan merawat anaknya karena ibu tidak bekerja diluar rumah untuk mancari nafkah. Namun hal ini tidak diimbangi dengan pemberian makanan yang baik dan bergizi pada anak balitanya. Sebagian besar ibu sudah pernah mendapatkan informasi atau penyuluhan tentang pemenuhan gizi pada anak 1000 hari pertama kehidupan/ Golden Perioed dengan status gizi yaitu sebanyak 27 (52,9\%). Berkembangnya berbagai media cetak maupun elektronika semakin kuat untuk memudahkan ibu mendapatkan berbagaikan informasi khususnya tentang pemenuhan gizi pada anak 1000 hari pertama kehidupan/ Golden Perioed.

Mayoritas responden juga sudah mendapatkan penyuluhan tentang pemenuhan gizi pada anak 1000 hari pertama kehidupan/ Golden Perioed yaitu $52,9 \%$. Ibu yang sebagian besar ibu rumah tangga juga mempunyai banyak waktu luang untuk menghadiri penyuluhan yang 
dilakukan oleh bidan dan juga dapat mencari atau mendapatkan informasi baik di media cetak maupun media massa. Informasi yang didapatkan dari berbagai sumber tentang hubungan seksual selama kehamilan akan mempengaruhi pengetahuan ibu dalam pengetahuan pemenuhan gizi pada anak 1000 hari pertama kehidupan/ Golden Perioed.

\section{Tabel 2. Perilaku pemenuhan gizi pada anak 1000 hari pertama kehidupan/ Golden Perioed dan status gizi balita}

\begin{tabular}{ccc}
\hline Perilaku \& Status gizi & jumlah & $\%$ \\
\hline Perilaku Ibu & & \\
Kurang & 26 & 51,0 \\
Baik & 25 & 49,0 \\
Status Gizi Balita & & \\
Kurang & 27 & 52,9 \\
Normal & 24 & 47,1 \\
\hline
\end{tabular}

Hasil survey menunjukkan ibu sebagian besar mempunyai perilaku yang kurang didalam pemenuhan gizi pada anak 1000 hari pertama kehidupan/ Golden Perioed (51,0\%). Menurut Lewit yang dikutip oleh Notoatmodjo, perilaku merupakan hasil pengalaman dan proses interaksi dengan lingkungannya yang berwujud dalam bentuk pengetahuan, sikap dan tindakan sehingga diperoleh keadaan seimbang antara kekuatan pendorong dan penahan (Maulana, 2009).

Perilaku ibu dapat dilihat dari sejak dari ibu hamil hingga anak berusia 2 tahun. Anak yang sehat hanya mungkin dilahirkan dari seorang ibu yang menjaga kehamilannya dari asupan gizi yang cukup (gizi mikro dan protein). Ibu hamil yang yang mengalami kekurangan gizi kronik sejak masa kehamilannya akan berisiko melahirkan anak yang kurang sehat, atau berat badan lahir rendah (Priyatna, 2014).

Perilaku ibu dalam pemenuhan gizi pada anak 1000 hari pertama kehidupan/ Golden Perioed selama kehamilan dapat dilihat dari Makan lebih banyak (dua porsi) dan beraneka ragam lauk pauk, sayur dan buah, agar kebutuhan gizi janin terpenuhi dengan cukup sejak awal dan selama masa kehamilan, dan minum tablet tambah darah 1 butir sehari, berarti total minimal 90 butir selama masa kehamilan, Jangan merokok, jangan minum minuman bersoda, beralkohol, jangan makan mie instan sebagai makanan pokok, hindari makanan berpengawet, dan jangan minum obat tanpa resep dokter. mengikuti kelas ibu hamil, dan melakukan perawatan payudara untuk menjamin keberhasilan pemberian ASI, serta melakukan kunjungan pemeriksaan kehamilan ke Bidan, minimal 4 kali selama masa kehamilan untuk memantau pertumbuhan janin (Irawati, 2018).

Telah diketahui bahwa kebutuhan gizi akan meningkat selama kehamilan yaitu pertambahan energi sekitar $330 \mathrm{kkal}$ per hari, pertambahan ini diperlukan untuk pertumbuhan jaringan ibu seperti penambahan volume darah, uterus dan payudara serta pertumbuhan janin (Erna, 2017).

Berdasarkan analisis peniliti dari hasil kuesioner yang diberikan ibu yang mempunyai perilaku kurang dalam pemenuhan gizi pada anak 1000 hari pertama kehidupan adalah mayoritas ibu tidak pernah melakukan perawatan payudara sehingga setelah lahir anak belum siap dilakukan pemberian ASI. Hal ini juga dapat ditegaskan dalam penelitian Haeriyanti (2016), untuk mengetahui hubungan perawatan payudara selama hamil dengan produksi ASI didapatkan hasil analisis statistik dengan uji chi square 
yaitu terdapat hubungan antara perawatan payudara selama hamil dengan produksi ASI didapatkan P 0,0041 ( $\mathrm{P}<0,05)$.

Ibu juga mayoritas kurang didalam mengkonsumsi tablet tambah darah. Kebutuhan zat gizi mikro seperti zat besi, asam folat dan kalsium juga meningkat. Untuk kebutuhan gizi meningkat $200 \%$. Hal ini diperlukan untuk pembentukan plasenta dan sel darah merah dan disarankan menelan 90 tablet selama kehamilan. Suplemen zat besi dan asam folat juga untuk mencegah anemia pada ibu dan kejadian BBLR pada bayi (Erna, 2017). Sesuai penelitian dari iriyani K (2016), berdasarkan hasil uji statistic Chi Square diperoleh nilai $\rho$ value $=0,001 \quad(<0,05)$ maka dapat disimpulkan bahwa ada hubungan pemberian suplemen Fe pada ibu hamil. Hasil perhitungan Risk Estimate diperoleh $\mathrm{OR}=8,25$, yang artinya ibu hamil yang mengkonsumsi suplemen Fe kurang dari 90 tablet mempunyai peluang 8,25 kali melahirkan bayi dengan BBLR dibandingkan dengan ibu hamil yang mengkonsumsi lebih dari 90 tablet Fe.

Didapatkan juga mayoritas ibu kurang menkonsumsi garam beryodium. Kebutuhan yodium sangat penting selama kehamilan. Yodium merupakan bahan dasar tiroksin yang berfungsi dalam pertumbuhan dan perkembangan otak bayi. Ibu hamil dianjurkan untuk menambah asupan yodium sebesar $50 \mu \mathrm{g} / \mathrm{hari}$ sedangkan sebelum hamil kebutuhan ibu adalah $150 \mu \mathrm{g} /$ hari.

Perilaku ibu dalam pemenuhan gizi pada anak 1000 hari pertama kehidupan/ Golden Perioed juga dapat dilihat dari saat bayi lahir yaitu dengan melakukan Inisiasi Menyusu Dini (IMD) langsung setelah bayi lahir, dan inisiasi ini sangat mendukung keberhasilan pemberian ASI Eksklusif. Memberikan ASI secara Ekslusif mulai bayi usia 0 - 6 bulan, dan semua kebutuhan gizinya sampai dengan usia 0-6 bulan sudah terpenuhi dengan sempurna hanya dengan ASI saja. Setelah usia 6 bulan sampai usia 2 tahun, meneruskan pemberian ASI dengan makanan tambahan pendamping ASI (MP ASI), menimbang bayi tiap bulan di Posyandu untuk dipantau tumbuh kembangnyaa. memberikan kapsul vitamin A dan imunisasi lengkap sesuai jadwal serta mencuci tangan pakai sabun dengan air mengalir sebelum memberi ASI.

Berdasarkan analisis peniliti dari hasil kuesioner yang diberikan ibu yang mempunyai perilaku kurang dalam pemenuhan gizi pada anak 1000 hari pertama kehidupan pada saat setelah melahirkan adalah mayoritas tidak dilakukannya IMD (Inisiasi Menyusui Dini) termasuk juga tidak mendapatkan atau kurang memberikan kesempatan kepada bayinya untuk memperoleh kolostrum /cairan pertama yang dikeluarkan warna kuning, kental (Erna, 2017).

Inisiasi menyusui dini (IMD) adalah inisiasi yang dilakukan ketika bayi lahir, tali pusat dipotong, lalu dilap kering dan langsung diberikan pada ibu. Harus ada sentuhan skin to skin contact, dimana bayi tidak boleh dipisahkan dulu dari ibu. Yang perlu dijaga adalah suhu ruangan, dan sebaiknya bayi memakai topi, karena pada bagian kepala merupakan daerah yang banyak mengeluarkan panas(Roesli 2007). Beberapa manfaat dari IMD antara lain adalah Bayi yang diberi kesempatan menyusu dini lebih berhasil menyusui eksklusif dan akan lebih lama disusui, hentakan kepala bayi ke dada Ibu, sentuhan tangan bayi di puting susu dan sekitarnya, emutan, dan jilatan bayi pada puting Ibu merangsang pengeluaran hormon oksitosin yang dapat membantu pengeluaran ASI dan bayi juga bisa mendapatkan ASI kolostrum- ASI yang pertama kali keluar. Cairan emas ini kadang juga, dinamakan the gift of life. Bayi yang diberi kesempatan inisiasi menyusui dini lebih dulu mendapatkan kolostrum daripada yang tidak diberi kesempatan. Kolostrum berkhasiat untuk membuat bayi tetap merasa kenyang untuk hari-hari pertamanya sebelum ASI bisa keluar dengan lancar (Roesli, 2007). Hal ini selaras dengan penelitian dari Ridha 
(2014), hasil penelitian menunjukkan ada pengaruh yang signifikan antara inisiasi menyusui dini terhadap produksi ASI. Terlihat dari hasil variabel produksi ASI pada responden yang melakukan inisiasi menyusui dini yang normal sebesar $87,5 \%$ $(p<0,05 \%)$ dan lebih sebesar 12,5\% $(\mathrm{p}<0,05)$. Sedangkan produksi ASI pada responden yang tidak melakukan inisiasi menyusui dini, produksi ASInya kurang semua atau sebesar $100 \%$ dimana $\mathrm{p}<0,05$ (Ridha, 2014)

Berdasarkan survey dari kuesioner Jarang ibu yang memberikan bayinya secara ekslusif. Bayi yang mendapatkan ASI mempunyai kenaikan berat badan yang baik setelah lahir, pertumbuhan setelah periode perinatal baik, dan mengurangi kemungkinan obesitas. Ibu-ibu yang diberi penyuluhan tentang ASI dan laktasi, umumnya berat badan bayi (pada minggu pertama kelahiran) tidak sebanyak ibu-ibu yang tidak diberi penyuluhan. Alasannya ialah bahwa kelompok ibu-ibu tersebut segera menghentikan ASInya setelah melahirkan. Frekuensi menyusui yang sering (tidak dibatasi) juga dibuktikan bermanfaat karena volume ASI yang dihasilkan lebih banyak sehingga penurunan berat badan bayi hanya sedikit (Kristiyansari, 2009). Menurut penelitian dari sulistya (2014) menunjukkan bahwa ada hubungan pemberian ASI ekslusif dengan status gizi balita usia 12-59 bulan dengan nilai $\mathrm{p}$ sebesar $0,039(\mathrm{p}<0,05)$. Berdasarkan data Dinkes Brebes jumlah bayi yang diberi Asi ekslusif di daerah sitanggal tahun 2015 adalah 74,64\%.

Ibu juga minoritas tidak menkonsumsi Vitamin A merupakan suplementasi yang diberikan pada ibu menyusui selama masa nifas yang memiliki manfaat penting bagi ibu dan bayi yang disusuinya. Vitamin A berfungsi dalam sistem penglihatan, fungsi pembentukan kekebalan dan fungsi reproduksi. Pemberian kapsul vitamin A bagi ibu nifas dapat menaikkan jumlah kandungan vitamin A dalam ASI, sehingga pemberian kapsul vitamin A (200.000 unit) pada ibu nifas sangatlah penting. Hasil penelitian menunjukkan cakupan pemberian vitamin A dosis tinggi di wilayah Bantul Timur adalah tinggi (90.48\%) namun masih ditemukan $9.52 \%$ tidak memberi kapsul vitamin A ibu nifas. Pemberian kapsul pertama diberikan pada ibu 24 pasca melahirkan sebanyak $100 \%$ sedangkan pemberian kapsul kedua tergolong kecil yaitu $52.63 \%$. Faktor tidak meratanya pemberian kapsul kedua diantaranya adalah kurangnya ketersediaan kapsul yang dimiliki tenaga kesehatan

Sedangkan dari status gizi anak hasil survey menunjukkan sebagian besar anak memiliki status gizi kurang yaitu 49,0 $\%$. Status gizi adalah suatu keadaan yang ditunjukkan oleh keseimbangan antara asupan dan pemakaian zat gizi dalam tubuh. Status gizi baik yaitu keadaaan dimana asupan zat gizi sesuai penggunaan untuk aktifitas tubuh. Keadaan kurang gizi (status gizi kurang dan status gizi buruk) terjadi karena tubuh kekurangan satu atau beberapa zat gizi yang diperlukan Gizi lebih adalah suatu keadaan karena kelebihan konsumsi pangan yang berkaitan dengan kelebihan energi dalam hidangan yang dikonsumsi relative terhadap kebutuhan penggunaannya. Kebutuhan zat gizi pada anak laki-laki berbeda dengan anak perempuan dan biasanya lebih tinggi karena anak laki-laki memiliki aktivitas fisik yang lebih tinggi (Depkes, 2009).

\section{Tabel 3. Hubungan perilaku pemenuhan gizi pada anak 1000 hari pertama kehidupan/ Golden Perioed dengan status gizi balita}

\begin{tabular}{llllll}
\hline \multirow{2}{*}{ Perilaku } & \multicolumn{4}{c}{$\begin{array}{c}\text { Status gizi } \\
\text { balita }\end{array}$} & $\mathrm{p}$ \\
\cline { 2 - 6 } & $\mathrm{K}$ & $\%$ & $\mathrm{~N}$ & $\%$ \\
\hline Kurang & 0 & 4,1 & 7 & 5,9
\end{tabular}


JURNAL ILMU KESEHATAN BHAKTI HUSADA:

HEALTH SCIENCES JOURNAL, Vol. 09 No. 01, JUNI 2018 DOI: https://doi.org/10.34305/jikbh.v9i1.58
Ciptaan disebarluaskan di bawah

Lisensi Creative Commons AtribusiNonKomersial-BerbagiSerupa 4.0 Internasional. Internasional.

\begin{tabular}{llllll} 
Baik & 7 & 29,2 & 17 & 70,8 & 0,0 \\
\hline
\end{tabular}

Hasil tabel 3. menunjukan bahwa ibu yang mempunyai perilaku baik dalam pemenuhan gizi pada anak 1000 hari kehidupan lebih banyak yang mempunyai anak dengan statug gizi normal yaitu 70,8 $\%$ dibandingkan dengan ibu yang mempunyai perilaku kurang yaitu $29,2 \%$. Hal ini menunjukkan ada kecenderungan semakin baik perilaku ibu dalam pemenuhan gizi pada anak 1000 hari kehidupan, maka semakin baik pula status gizi balitanya.

Berdasarkan hasil Uji statistik dengan chi square diperoleh nilai $\mathrm{p}=0,003$. Oleh karena $\mathrm{p}=0,003<\alpha(0,05)$ maka Ho ditolak, kemudian dapat disimpulkan bahwa ada hubungan secara bermakna perilaku ibu dalam pemenuhan gizi pada anak 1000 hari kehidupandengan status gizi balita. Nilai koefisien kontingensi (C) sebesar 0,410 yang artinya antara hubungan perilaku ibu dalam pemenuhan gizi pada anak 1000 hari kehidupan dengan status gizi balita mempunyai hubungan yang cukup kuat. Pada hasil OR yaitu 6,939 sehingga dapat diartikan ibu yang mempunyai perilaku ibu dalam pemenuhan gizi pada anak 1000 hari kehidupan mempunyai peluang 6,939 kali untuk memiliki anak yang mempunyai gaizi normal dibandingkan dengan ibu yang mempunya perilaku kurang didalam pemenuhan gizi pada anak 1000 hari kehidupan.

Hal ini sesuai dengan penelitian dari Suliyah (2010), yang bertujuan mengetahui hubungan perilaku ibu dalam pemberian makan dengan status gizi pada balita 13-59 bulan di posyandu Lada Pakuncen Wirobrajan Yogyakarta Tahun 2010 dengan hasil uji statistik nilai $\pi 0,379$ dengan taraf signifikan (p) 0,011 dengan taraf kesalahan $(0,05)$, maka dapat disimpulkan hubungan perilaku ibu dalam pemberian makan dengan status gizi pada balita usia 13-59 bulan mempunyai hubungan yang bermakna (Suliyah, 2010)
Kurangnya gizi pada balita dapat disebabkan sikap atau perilaku ibu yang menjadi faktor dalam pemilihan makanan yang tidak benar. Pemilihan bahan makanan, tersedianya jumlah makanan yang cukup dan keanekaragaman makanan ini dipengaruhi oleh tingkat pengetahuan ibu tentang makanan dan gizinya. Ketidaktahuan ibu dapat menyebabkan kesalahan pemilihan makanan terutama untuk anak balita (Mardiana, 2005). Penelitian dari Nainggolan (2012), yang dilakukan dengan metode observasional dengan pendekatan cross-sectional. Populasi dalam penelitian ini seluruh Ibu dari balita yang menjadi responden di wilayah kerja Puskesmas Rajabasa Indah kelurahan Rajabasa Raya yang berjumlah 264 respoden. Sampel yang digunakan sebanyak 159 responden dengan teknik pengambilan sampel secara Accidental sampling. Analisis Bivariat menunjukkan ada hubungan yang signifikan antara pengetahuan gizi Ibu dengan status gizi balita dan ada hubungan yang signifikan antara sikap gizi Ibu dengan status gizi balita $(\mathrm{p}=0,000)$.

\section{Kesimpulan}

Berdasarkan hasil penelitian
menunjukkan ibu sebagian besar mempunyai perilaku yang kurang didalam pemenuhan gizi pada anak 1000 hari pertama kehidupan/ Golden Perioed yaitu $51,0 \%$. Sedangkan dari status gizi anak hasil survey menunjukkan sebagian besar anak memiliki status gizi kurang yaitu 49,0 $\%$. Berdasarkan hasil Uji statistik dengan chi square diperoleh nilai $\mathrm{p}=0,003$. Oleh karena $\mathrm{p}=0,003<\alpha(0,05)$ maka Ho ditolak, kemudian dapat disimpulkan bahwa ada hubungan secara bermakna perilaku ibu dalam pemenuhan gizi pada anak 1000 hari kehidupan dengan status gizi balita. Nilai koefisien kontingensi (C) sebesar 0,410 
yang artinya antara hubungan perilaku ibu dalam pemenuhan gizi pada anak 1000 hari kehidupan dengan status gizi balita mempunyai hubungan yang cukup kuat. Pada hasil OR yaitu 6,939 sehingga dapat diartikan ibu yang mempunyai perilaku ibu dalam pemenuhan gizi pada anak 1000 hari kehidupan mempunyai peluang 6,939 kali untuk memiliki anak yang mempunyai gaizi normal dibandingkan dengan ibu yang mempunya perilaku kurang didalam pemenuhan gizi pada anak 1000 hari kehidupan.

Diharapkan kepada ibu balita hendaknya lebih memberikan makanan yang bergizi dan cukup energi untuk anaknya, aktif dalam mengikuti kegiatan posyandu setiap bulannya untuk memantau pertumbuhan dan perkembangan anak balita. Perlunya semakin meningkatkan pemantauan status gizi balita di setiap posyandu sehingga balita dengan status gizi kurang terjaring secara dini dan mendapat penanganan segera.

\section{Daftar Pustaka}

Achadi, A., W. Soerojo, and S. Barber. (2005). "The Relevance and Prospects of Advancing Tobacco Control in Indonesia." Health Policy 72 (3): 33349.

Achadi EL. 2014. Periode Kritis 1000 Hari Pertama Kehidupan dan Dampak Jangka Panjang terhadap Kesehatan dan Fungsinya. Fakultas Kesehatan Masyarakat. Universitas Indonesia

Almatsier, S. 2001. Prinsip Dasar Ilmu Gizi. Jakarta: Gramedia Pustaka Utama.

Apooh, Yaa, L., \& Krekling, S. 2005. Maternal nutritional knowledge and child nutritional status in the volta region of Ghana. London: Blackwell Publishing

Badan Penelitian dan Pengembangan Kesehatan Departemen Kesehatan RI. Riset Kesehatan Dasar (RISKESDAS). Laporan Nasional 2013. Jakarta
BAPPENAS.2011. Rencana Aksi Nasional Pangan dan Gizi 2011 - 2015. BAPENNAS

Departemen Kesehatan RI. 2007. Pedoman Pelaksanaan Stimulasi, Deteksi Dan Interval Dini Tumbuh Kembang Anak. Jakarta: Departemen Kesehatan RI.

Departemen Kesehatan RI. 2009. Buku Saku Gizi. Jakarta : Departemen Kesehatan RI.

Departemen Kesehatan RI. 2015. Kesehatan dalam Kerangka Sustainable Development Goals (SDGs). 2015. 4 Juni 2018.http://www.pusat2.litbang.depke s.go.id/pusat2_v1/wpcontent/uploads/ 2015/12/SDGs-Ditjen-BGKIA.pdf

Erna, Yasmina.2017. 1000 hari Pertama Kehidupan. Pandan wangi: Majalah Hijrah. Ed. 68 Vol.6 (September 2017) Haeriyati. 2010. Hubungan Perawatan Payudara dengan Produksi ASI pada Ibu Nifas di RSUD Sinjai (Skripsi. UN Alauddin Makasar. Mak

Hidayat AAA. 2007. Metode Penelitian Kebidanan Dan Teknis Analisis Data. Jakarta: Salemba Medika.

Irawati ,2018. ada apa dengan 1000 hari Pertama Kehidupan Sang anak. 2 Mei 2018.

https://www.tanyadok.com/artikelkesehatan/ada-apa-dengan-1000-haripertama-kehidupan-sang-anak .2 Mei 2018.

Iriyani K. 2016. Hubungan Pemberian Suplemen Zat Besi Pada Ibu Hamil dengan BBLR di RSUD Abdul Wahab Sjahrani Samarinda. Jurnal Ilmiah Manuntuang, 2 (1), 56-59.

Mardiana. 2006. Hubungan Perilaku dengan Status Gizi Balita di Puskesmas Tanjung Beringin Kecamatan Hinai Kabupaten, Skripsi Program S1 Ilmu kesehatan Masyarakat Fakultas Kesehatan Masyarakt Universitas Sumatera Utara.

Maulana HDJ. 2009. Promosi Kesehatan Yudha EK, editor. Jakarta: EGC

Nainggolan, Julita. 2012 Hubungan Antara Pengetahuan dan Sikap Gizi Ibu 
dengan Status Gizi Balita di Wilayah Kerja Puskesmas Rajabasa Indah Kelurahan Rajabasa Bandar Lampung (Skripsi). Fakultas Kedokteran Universitas Lampung

Notoatmodjo. 2003. Pendidikan Dan Perilaku Kesehatan. Jakarta: Rineka Ilmu.

Priyatna A. 1000 hari Pertama Kehidupan. 2014. PT Elex Media kompurindo. Jakarta

Ridha, Rusmiyati, Purnomo. 2014. Pengaruh Inisiasi Menyusui Dini Terhadap Produksi Asi Pada Ibu Post Partum di Ruah Bersalin Semarang. Jurnal Ilmu Keperawatan dan Kebidanan (JIKK)

Roesli, U. 2005. Mengenal ASI ekslusif. Jakarta : Trubus Agiwidya

Sulistya. 2014. Hubungan pemberian asi ekslusif dengan status gizi balita usia 12-59 bulan di posyandu dewi sartika candran Sidoarum Sleman Tahun 2014 (Skripsi). Yogya: Aisyiyah yogykarta

Suliyah. 2010. Hubungan perilaku Ibu Dalam Pemberian Makan Dengan Status Gizi Pada Balita Usia 13-59 Bulan Di Posyandu Lada V Pakuncen Wirobrajan Yogyakarta Tahun 2010 Suliyah, anjarwati, stikes aisyiyah yogya 
JURNAL ILMU KESEHATAN BHAKTI HUSADA:

HEALTH SCIENCES JOURNAL, Vol. 09 No. 01, JUNI 2018

DOI: https://doi.org/10.34305/jikbh.v9i1.58
Ciptaan disebarluaskan di bawah Lisensi Creative Commons AtribusiNonKomersial-BerbagiSerupa 4.0 Internasional. Internasional. 